\title{
DISSIMILAR CULTURAL PATTERNS AND HYBRID IDENTITIES IN JAMIL AHMED'S SELECTED LITERARY FICTION
}

\author{
Hassan Bin Zubair ${ }^{1 *}$, Syeda Sughra Naqvi ${ }^{2}$ Saima Larik ${ }^{3}$
}

${ }^{1 *}$ PhD Scholar (English Literature), Department of English, National University of Modern Languages, Islamabad, Pakistan; ${ }^{2} \mathrm{PhD}$ in Anglophone Studies (France), Department of English, Govt. Postgraduate College Sahiwal, Pakistan; ${ }^{3} \mathrm{PhD}$ Scholar (English Literature), Lecturer (English), Department of Linguistics \& Social Sciences, Begum Nusrat Bhutto Women University, Sukkur, Pakistan.

Email: ${ }^{1 *}$ hbz77@yahoo.com, ${ }^{2}$ punjtani512@ymail.com, ${ }^{3}$ saimalarik0@gmail.com

Article History: Received on $17^{\text {th }}$ March 2021, Revised on $27^{\text {th }}$ June 2021, Published on $30^{\text {th }}$ June 2021

\begin{abstract}
Purpose of the Study: The present research discusses shifting cultural location renders a hybrid identification in Ahmad's The Wandering Falcon. In having readjustment in a new location, a person imitates a way of living, ultimately redefining one's identity.
\end{abstract}

Methodology: The novel projects the pivotal character Tor Baz as a displaced person who adopts Mullah tribal culture to adjust to a new situation. As Bhabha's notion about hybrid identity shows, modern cultural locations are being formed where a person influences different cultural patterns.

Main Findings: Culture remains an inseparable factor in human beings, and every being belongs to a particular cultural identity. While shifting cultural locations, a person has to change the way of living in which the person faces dilemmatic as well as physical and psychological crises.

Application of the Study: The study contributes to the field of research in hybrid identification and cultural identities.

Novelty/originality of this Study: Culture remains an inseparable factor in human beings and every being belongs to a particular cultural identity. The originality of the research is that it studies the shift of cultural locations; a person has to change the way of living in which the person faces dilemmatic as well as physical and psychological crises.

Keywords: Culture, Identity, Hybridity, Shifting, Community, Liberalism, Pakistan.

\section{INTRODUCTION}

The novel identifies a cultural dilemma when people encounter more than a single cultural standard. A person has a forceful situation as such a location where one should act with a multicultural identity. Every human being is identified by a particular culture that has been the identity of any person. This source of culture always determines a person's life and life patterns. A composite cultural life is divided along with shifting new cultural zone. The Parsee culture defines Tor Baz's identity as a community member that is no longer intact when he moves into another cultural location. It justifies how a man feels when he is away from his own culture. Tor Baz's experience is bitter with a new settlement where he cannot communicate with them, understand their lifestyles, and assimilate all norms and values. He realizes the cultural gap between his own culture and the new culture there by which his life is painful and disappointed. It is a dual cultural standard where Tor Baz acts like a hybrid man having both cultural traits. Having felt cultural loss, he feels cultural ambiguity and confusion. The novel The Wandering Falcon projects the Tor Baz as an 'experiencer' of a hybrid character who accumulates more than a cultural practice. He faces a kind of persistent journey on which he endeavors to exist. A new tribal community, Mullah as a typical cultural group, receives him; but Tor Baz does not easily adjust to him there. A person acts being closer to destination culture to find better adjustment. Shifting from one culture to another can be essential for changing cultural patterns as well. A person needs to be adaptable to a new place. David Anderson that

"The fusion of two cultures. Western English culture, colored strongly by post- Darwinian determinism and pessimism is merged with the Eastern Muslim the culture that combines a reverence for life with a sense of hope. This fusion has become particularly important in the Pakistani literary tradition" (Anderson 1971: 81)

The process of changing patterns in his life brings physical difficulty and psychological torture. Tor Baz grew up in a typical Parsee culture where he spent his early childhood. As Parsee's cultural practices, he attributes all cultural patterns like life patterns, religion, language, and each conduct of everyday behaviors. "The novel openly questions religion in its depiction of the conflict between religious tradition and western progressive philosophy" (Kaleta 1998, p.48). The entire factors define his cultural identity, which is different and unique. As such socio-cultural values overall define human identity. But, a person can be influenced when one comes into contact with a different cultural society. The central character of the novel Tor Baz begets in a Parsee cultural community. The community is a small tribal one that has a different cultural practice. The community undergoes natural disasters, which influences their settlements. Having a survival crisis Tor Baz and his parents move toward the border side of Afghanistan, where they encounter a different tribal community. Rath says: 
"The most common manifestation of one's otherness in an alien culture is a question one encounters from time to time: Where are you from? Not 'Who are you?' Its follow up is often 'No, I mean where you are really from' and 'what brought you here from there?'" (Rath, 2003,p.5).

In the new location, they find a different cultural practice from which Tor Baz influences. Coming into contact with different cultures, he cannot find a unified identity. Tor Baz finds a peculiar experience while he adopts a distinct and contrasting cultural pattern. It makes it more difficult for him to modify his way of living. It shows that "[a]s migrants cross borders, they also cross emotional and behavioral boundaries, One's life and roles change. With them, identities change as well" (Espín, 2006, p.241). All living patterns are incompatible with his source cultures. However, Tor Baz endeavors to accommodate himself there. But, Tor Baz undergoes both physical and mental sufferings. This cultural shifting renders tearing his unified cultural self. As a matter of fact, neither does he continue his original self nor change him completely in the new tribal culture. Simultaneously, he maintains both cultural traits in which he acts like a nowhere man. Lau states that "the geographical locations of the authors influence, to no small degree, their approach to writing in English, the audience for whom they write, and the concerns which they choose to draw attention towards" (Lau, 2005, p.238).

\section{RESEARCH OBJECTIVES}

- To highlight the cultural effects and national affiliations among Jamil Ahmed's The Wandering Falcon.

- To present different cultural patterns in the selected text.

- To analyze the role of religion in the society presented in the selected text.

\section{RESEARCH QUESTIONS}

Q. 1: How has Jamil Ahmed presented the novel's dissimilar cultural patterns?

Q. 2: How has cultural and societal diversity urged people to search for their identity in a hybrid culture/state?

\section{RESEARCH METHODOLOGY AND THEORETICAL FRAMEWORK}

This research is qualitative in nature. This novel has been studied from several perspectives, and all the critics claim its meaning and interpretation. Till now, an innovative critical insight has not been used; therefore, the research forwards cultural hybrid as a critical tool to eye the novel. This research mainly takes Homi. K. Bhabha's concept of cultural location after the post-colonial world where new cultural locations are being established. And equally, Stuart Hall's idea about human identity is used. Regarding the concept of hybrid identity, Bhabha argues that Hybridity is a post-colonial phenomenon; nevertheless, it had existed as a concept. Historically, it has been connected with the political period because Hybridity had associated with post-colonial projects when the world came to contact each other. Liberalism and globalization promoted this concept of Hybridity by creating open-world policy. Along with the new socio-political world, everything has been redefined and reframed. After the post-colonial world, one of the most dominant ideas is shifting identity and hybrid experience. Previously, cultural identity was a common issue when all cultures were intact. But, it became a dominant question for human beings when a multicultural world turned up. It is also an experience of a multicultural world where more cultural presence influences human identity.

Along with socio-cultural shifting, even social concepts have been changed. It also speeds up human movements from place to place. This kind of new scenario also introduces a different environment regarding human identity. Stuart Hall defines "cultural identity in terms of one, shared culture, a sort of collective one true self, hiding inside the many other, more superficial or artificial imposed selves, which people with a shared history and ancestry hold in common. It is called identity as offering a sense of unity and commonality" (Hall, 1997, p.32; Ullah 2020). Cultural identity is a concept that defines a person from his socio-cultural background. Bhabha claims; "all forms of culture are continually in the process of hybridity" (Bhabha, 1994, p.211; Khan, Ullah, Usman, Malik, Khan, 2020). Furthermore, Hoogvelt discusses on:

"In fact, the concept of Hybridity occupies a central place in post-colonial discourse. It is celebrated and privileged as a kind of superior cultural intelligence owing to the advantage of in-betweenness, the straddling of two cultures and the consequent ability to negotiate the difference" (Hoogvelt, 1994, p.158).

Cultural identities are constantly produced and reproduced by regular shifting. It means that when an individual lives in a new location who copies new cultural habits and conducts for adjustment there. Shahnaz Khan states, "Hybridized subjects initiate new signifiers and symbols of identities" (Khan,2002, p.22; Ullah 2020). Bhabha reinforces his idea of the cultural location, which means not a new place but a place where new cultures are found and encountered. When different cultures are met together, a new culture is formed after many exchanges among different cultures at the same time. The same kind of cultural location Bhabha introduces in his idea. Hybridity creates a situation in which different cultures interact with them. A person who accommodates as such a cultural location certainly forms a hybrid identity. 


\title{
PAKISTANI BACKDROP
}

The novel simply introduces an orphan boy's story, which begins in Pakistan. A small Parsee tribal community undergoes physical suffering along with natural disasters. Among the group, a Tor Baz's family also leaves the place and set for a new one. In search of a better life and place, they reached the border between Pakistan and Afghanistan. In the course of reading the novel, Alan Cheuse analyzes it from a different standpoint:

\begin{abstract}
"We read of lovers fleeing the deadly punishment of their tribal group, of women desperate for affection, buried under customs and habits millenniums old, of men of honor living lives of crime, of tribal members returning from the exile who must carefully navigate each clan and subclantostay honorable and sometimes to stay alive." (Cheuse, 2011, p.5)
\end{abstract}

As his claim, cultures are being encroached on by mainstream culture. Human beings are engulfed by mainstream or popular cultures in this modern society. Similarly, the novel digs out how cultures are being clashed against mainstream cultures. Historically, it is a condition of the post-colonial period, where almost all local tribes and local cultures have been critical regarding their existence. In contrast, Rowan Kaiser develops a new insight while reading the novel. As he reproduces existential meaning in the novel, it can be a new critical outlook while interpreting the novel:

"The Wandering Falcon is an elegy for a disappearing way of life in the mountains of Afghanistan and Pakistan. But where most stories of that sort explain the loss of culture by saying that the march of progress cannot be stopped, there's no progress in The Wandering Falcon. There's simply the slow increase of the power of the state in the middle of the 20th century, ending one harsh way of life without replacing the conditions that made it so harsh." (Kaiser, 2011, p.243)

This critic deals with the existential problems of tribal communities due to the globalization and influence of mainstream cultures. Having the regular influence of different cultures surviving problems are challenging tribal people. The tribal communities struggle for existence, but such minorities have a critical situation for fighting against the majority. The author creates an imaginative world in which his narrative lines flow. Furthermore, he puts his words:

"It would be a failure of imagination not to make the connections between Jamil Ahmad's fictionalized history and what is happening today in Afghanistan and his homeland of Pakistan. The mountains, deserts and broken hills of The Wandering Falcon is the same ones that CIA drones fly over. The suspicion of outsiders, the shifting sands of tribal allegiances and the cycles of vengeance are familiar." (Jenning, 2012, p.180)

He emphasizes the fictional representation of the novel, Ahmad manipulates his imaginative power through which he overstates to reality. This novel entails the author imaginative power to represent the world. While representing the world, Ahmad heavily exploits his artistic power in the novel. Furthermore, Mariana Baabar argues on political conflict during the globalization period. It shows how a smaller group from different tribes resists surviving. As a result, the novel also addresses a similar point of view here:

"The turmoil in the tribal areas of Pakistan and Baluchistan, the reign of terror, the drone attacks, the relentless blood-letting deeply saddens him. The anger in Baluchistan has been building up for 60 years. He isn't willing to indulge in a blame game, confining himself to saying the mayhem there is the handiwork of actors. Traditionally, there was a mullah uprising in every generation." (Baabar, 2011, p.21)

It explains the modern cultural situation in which multicultural societies are being formed. Due to the contact of different races, cultures, and communities, new cultural locations are being formed in which human identities cannot remain uninfluenced by other cultures.

\section{ANALYSIS}

The research introduces a bit different situation in which the protagonist forms his identity. Tor Baz belongs to the particular Parsee culture, but he leaves his cultural location and shifts into another community where he practices new culture. This is also a post-colonial situation when human beings change their locations encounter dual cultural standards. Tor Baz is an experience of colonial hybrid identity when he travels one after another cultural location. The research raises a hybrid identity as a post-colonial experience. It also shows the reformulation of human identity and shifting cultural zone in Jamil Ahmad's The Wandering Falcon. The principal character, Tor Baz, represents a hybrid character of the post-colonial period, which shows how human beings are impinged by a multicultural world. Tor Baz experiences a hybrid identity when he rearranges his shifting into a different community. He has been a victim of the new society where he cannot find his way of life. The major character Tor Baz faces a new cultural phenomenon when he shifts into a Mullah community. Tor Baz belongs to a Parsee cultural origination. It is a traditional and typical cultural group that follows conventional practices in society. It is a small cultural group from Pakistan that hardly sustain their 
lives. The cultural group has basic problems that are unable to fulfil basic needs. The tribal community has to struggle against all kinds of natural disasters without having material resources with them. Due to such reasons, Tor Baz leaves his home with his parents. Though, being a small cultural group has a different identity in society. The pivotal character Tor Baz experiences a hybrid cultural identity after he leaves his community. As the protagonist, Tor Baz is not tied within a particular locality. No socio-cultural aspects hook him; therefore, he lives a lonely life outside of his society. It means the particular social forms and imparts an identity with specific norms, values, and ideologies by which human identities are defined. But, along with a detachment of their own culture, Tor Baz loses the identification of his particular society. Gaurav Desai emphasizes that

"Every human being is held by a society, no matter how free and open the society, no matter how bohemian the individual. In any case, the intellectual is supposed to be heard from and, in practice, ought to be stirring up debate and, if possible, controversy. But the alternatives are not total quiescence or total rebelliousness" (Deasi, 2005,pp.96-97).

Tor Baz experiences more than a single culture that influences his cultural personality. As being a wanderer, Tor Baz encounters different cultural patterns in a different community. He practices diverse cultural practices when he leaves his home regarding his cultural living. As soon as he involves in another culture, his feeling seems problematic. As soon as they leave their society, they are influenced by different cultures and locations. The novel projects cultural Hybridity as a modern cultural option when a person lives in another culture. In another culture, a person is influenced by a different culture. A person is guided by their cultural patterns and all kinds of attitudes and behaviors. Culture defines personal attributes and attitudes as Tor Baz represents a typical character from Parsee culture, but it can be influenced by another culture when he shifts into Mullah Community. Ngugi wa Thiong'o once stated, in rather Althusserian terms, that "Literature, as part of the culture, is really a reflection of the material reality under which we live ... I have come to realize that no people can develop a meaningful national culture under any form of foreign economic domination" (Thiongo, 1981, p.3). At the beginning of the novel, Tor Baz and his parents move from their community and take shelter in a different community. At first, Subedar does not accept them because they belong to a different cultural background. As his parents appealed to him, he hesitated. Due to the cultural difference, Subedar does not ease him to adapt to their society.

As Subedar asks Tor Baz's parents about their different cultural origination, he refuses to take them. But, Tor Baz's parents make a humble request with him because they have already left their house and community. He clarifies cultural differences as Tor Baz's family is from the Parsee culture, which is different from his own culture. Therefore, such a cultural difference makes adjusting to a new community more difficult. Due to the cultural difference, Subedar feels uncomfortable and then refuses them. Being from a different community, they hardly get refuge in Subedar's community. Ultimately, he swears them to have their way of living and let them stay there. All of them commit to following Subedar's cultural pattern. It becomes a compulsion for them because of having alien land; they should face all kinds of dominations and imposition. This chunk explains how Subedar imposes his cultural patterns on them. As long as they stay there, they should adopt their way of living. Due to the existential problems, Tor Baz and his parents follow their living practices. It becomes a secondary thing to mimic culture because they have undergone daily problems. Even for adjusting to a new culture, a person should accept all kinds of cultural livings. According to Bose, it is indispensable to scrutinize "the diverse and complex experiences of resettlement, integration and ongoing relationships with putative homelands" (Bose, 2008,p.120). A person has to change his lifestyle while the person shifts cultural location. It cannot be chosen, but it is an optional life. Without being closer to the destination culture, a person cannot exist in a new location. Similarly, Tor Baz undergoes compulsion because he does not have any option for living life. Therefore, he accepts his new way of living for adjusting and existing his life. His parents also assimilate as such commitment. Living life is the most important for them rather than adopting a new culture. It is a third space where Tor Baz and his parents live, and it is a compulsion for them to follow what the Subedar teaches them. Regarding such cultural shifting, Bhabha explains that "this third hybrid space is an ambivalent site where cultural meaning and representation have no primordial unity or fixity" (Bhabha, 1994, p.67). Similarly, Tor Baz, even being a small boy, feels the influence of another cultural domination. Even though he does not like Subedar's culture, he should follow for adjusting there. As living between two cultural standards, he accumulates both cultural traits. Bhabha argues regarding this idea:
"The third space is a mode of articulation, a way of describing a productive, and not merely reflective, space that engenders new possibility. It is an interruptive, interrogative, and denunciative space of new forms of cultural meaning and production blurring the limitations of existing boundaries and calling into question established categorizations of culture and identity." (Bhabha, 1994, p.68)

Certain norms and values bound cultural identity. As it is defined in terms of territory, culture, and tradition, but losing a particular location, a person does possess these specific values. In the same way, Tor Baz is detached from socioeconomic factors. The new community has a unique sort of cultural pattern that would be quite a wildlife. In the beginning, Subedar forces them to practice it, and they feel uncomfortable, but they do not have an option, and they gradually follow their way of living. Tor Baz does not find a homely environment and feels difficulty because society has different cultural patterns. Multiple cultures create multiple cultural positions. Tor Baz explains, "I have always lived 
with a little trouble of one kind or another" $(T W F, 83)$. A sense of belonging with source culture is dominant, which frequently haunts the person; however, the present situation modifies the person's life. As such, a situation creates selftorture and self-actualization in the world of cultural confusion. Regarding the postmodern human identities, Robert Young opines:

"Today's society as globalization requires employees from different cultures to collaborate. This has led to the concern towards remediating intergroup conflict. For example, previous research had found that teams were more likely to consider and use the knowledge of a previous outgroup member when contextual conditions highlighted the salience of the superordinate group rather than the subgroups." (Young, 1995, p.643)

Culture remains an important part of human beings. It is determined through location, relation, language, particular cultural pattern. All society develops its cultural patterns of society. Culture is part of human beings that is not separable from any individual. It means an individual is defined based on culture. Cultural identity posits human recognition of any specific culture. Tor Baz's cultural identity is redefined along with shifting in a new location. It is Mullah Community which practices a completely different pattern. The cultural group has a peculiar life pattern and loves having forest lives.

Tor Baz's family realizes a cultural gap between their and new communal practices. This situation frustrates them; hence, parents think about fleeing from there. The unique cultural practices complicate their life there. To practice a new culture is difficult for each human being. Ajaya Kumar Sahoo defines an individual's identity as "how one sees the world from a particular position and relative to what aspects or how one experiences self-hood" (Sahoo, 2006, p.89). A person feels easier in a cultural location that has been digested by born. But, a sudden change in living makes complexity. An identity is a reflection of the social surroundings in which it is formed. Individual identity results from the social product of his/her surroundings. It is formed within cultural spaces. Tor Baz's identity is fragmented when he participates in the Mullah Community. Therefore, he continues both cultural livings because of the continual shifting. As Tor Baz finds difficult life outside of culture:

"The decision is not an easy one but decide we must as we have overstayed our welcome in this town, and the grass is giving out. We have to move, whether it is forward or backward. If we move back towards Afghanistan, we will be wandering until the winter is over and the snow melts in our highlands. These winter months will be bitter for us, our herds." (TWF, 56)

He does not find a sense of belongingness in Mullah culture; nevertheless, he practices it for adjustment. While living in another cultural life, he suffers from a sense of loneliness and cultural indifference. It explains: "To both sides, survival is the ultimate virtue. Neither community is any stigma attached to a hired assassin, a thief, a kidnapper, or an informer" $(T W F, 15)$. Living outside of society, Tor Baz does not feel comfortable in his life. Despite having bare harshness and difficulty, he tries to adjust there. The term hybridity is closely familiar with the idea of Bhabha that "Hybridity is the revaluation of the assumption of colonial identity through the repetition of discriminatory identity effects. It displays the necessary deformation and displacement of all sites of discrimination and domination." (Bhabha, 1994, p.42)

For this reason, all of them try to adjust there as much as possible. Therefore, Tor Baz thinks, "the terrible struggle for life makes it impossible for too much time to be wasted over thoughts for the dead" (TWF,34). He realizes hybrid and dramatic life there. Tor Baz acts in two ways of living. On the one hand, he practices his own Parsee culture in his home. On the other hand, he also accepts Mullah Culture. Tor Baz realizes his changing life along with daily practices. Subedar always wants to change him into his religion and culture. On the one hand, Subedar renames his cultural name; but he does not accept him. He encounters numerous problems; however, he cannot resist his part because it is difficult to fight with any obstacles. Nevertheless, his identity is reshaped as a hybrid man when both Parsee and Mullah cultural forms. It imparts him dual cultural identification in society. Tor Baz's life becomes alone when his parents are killed in a tribal war. Tor Baz realizes both kinds of mental suffering as he moves ahead, having a sense of better life. He changes his cultural identity when he shows both cultural patterns. As Mullah trains him to be a member of his culture, he is gradually influenced by the new culture. Mullah even tries to rename him from his own culture. This is a process of melting and tilting from one culture to another. Tor Baz also loses his cultural originality along with new settlements and new contexts. Ashcroft, Griffiths, and Helen discuss cultural influence in a new location:

"Place in post-colonial societies is a complex interaction of language, history, and environment. It is characterized firstly by a sense of displacement in those who have moved to the colonies or the more widespread sense of displacement from imported language, of a gap between the experienced environment and descriptions the language provides, and secondly by a sense of immense investment of culture in the construction of place." (Ashcroft et al., 1995, p.391)

It is a complex experience in another culture because a person has a sense of own cultural identity; however, the person cannot remain intact with it. But, a new context interprets life which is reality, and its own culture exists in mind. He further says, "One set of values, one way of life had to die. In this clash, the state, as always, proved stronger than the individual. The new way of life triumphs over the old" (Ashcroft et al., 1995, p.25). It makes a realization in his mind how new and old life should be balanced there. Because of mixed cultural identity, Tor Baz becomes a victim of both 
tribal cultural traits. When Tor Baz becomes closer with Mullah Culture after long practices with Subedar, his company with Subedar influences very much. Subedar also wanted to change his cultural identity as a member of Mullah. The new cultural orientation changes him to some extent. Tor Baz becomes a nowhere man. He understands his present situation where he has done for existence. He has a sense of his cultural origination and ever decides to return to his own culture after all. In the course of finding better lives, even his parents left their places; as a reason, his struggles for existence changes his self-defined world.

\title{
DISCUSSION
}

In the novel, Tor Baz gradually knows the value of cultural identity when he suffers from cultural imposition. Mullah's community always forces him to learn their language and religion. Having dual cultural standards, he hardly maintains his own life. Later on, Tor Baz leaves Subedar and joins Barrera, who also forces him to be a member of their community. Barrerai and Mustad, both of them, force him to move from there. Both of them are soldiers who want to take him to their office. Tor Baz has been split from social life and separated by cultural values. He does not have any permanency in their culture. His identity is being changed along with his shifting location." The aspects of migrants' lives that were largely ignored by much of the early transnational migration scholarship ought to be taken into account" (Levitt et al., 2005: 568). He claims over the relationship of man with location and culture. Hall believes that cultural identity exists only in representation. So, on this concept, he argues:

\begin{abstract}
"It is not as transparent or unproblematic as we think, perhaps instead of thinking of identity as an already accomplished fact, which the cultural practices then represent, we should think of identity as a production that is never complete, always in process, and always constituted within, not outside representation. This view problematizes the very authority and authentically to which the terms. Cultural identity lays claims." (hall, 1997, p.110)
\end{abstract}

This is the case, by narrating the stories of their self-torture and self-actualization in the world of cultural confusion; many post-colonial writers have been trying to create themselves to establish their identity through varying ways of expression. Tor Baz does not content with his life wherever he moves. He seeks his cultural life. But, he cannot find it, and it is not possible for him, who changes the different ways of living patterns in the different tribal communities.

He visits the different regions but does not settle at any place. Society constructs different norms and values by which human identity is constructed. Tor Baz cannot escape from his present situation. It means he experiences mixed cultural patterns in a new society. Eventually, Tor Baz accepts his hybrid identity as a new destination of life from which he cannot escape. He adopts different ways of living because he comes into contact with several tribal cultural patterns where he was trained. However, he does not forget his own culture. At times, he tries to return to his cultural world to enjoy his own cultural life. But, it becomes impossible when he entangles with different cultural traits.

\section{FINDINGS}

The research has projected a hybrid identity is an option in a multicultural world. A single culture defines a person's cultural identity, but it no longer remains when a person involves in dual cultural standards.

- Furthermore, it is practically difficult for the second cultural group to adjust to a new one. But, it does not have an optional choice except accepting hybrid identity. Hybridity is a mixed cultural identity that imitates destination culture.

- Ahmad has explored the post-colonial situation in which displaced people around the world act dual cultural identity. Due to the human movement from several cultural zones, they lose cultural identity and form a new identity as a hybrid.

- When a person practices more cultures, the person assimilates both cultural patterns. As Tor Baz changes his cultural location from Parsee culture to Mullah and Muslim culture, he loses his own cultural identity. His identity is defined as a hybrid identity with all these cultural patterns.

- At this present globalization, people disperse all over the world. Ahmad experiments on modern human identities not limited to one culture, and cultural locations are being melted due to the influence of other cultural existence. Even he has experienced such an experience while staying abroad than he shared through fiction.

- Similarly, this novel introduces the presence of more than one culture. As a major character, Tor Baz has different cultural originality. As a reason, he is brought up and shaped in his own culture. Tor Baz is taken to Mullah, Muslim and tribal culture, where he finds in-betweenness among different cultures. As a result, he gradually adopts other languages, life patterns, and ways of life.

Therefore, Bhabha represents and expresses; "The menace of mimicry is its double vision which disclosing the ambivalence of colonial discourses also disrupts its authority. It is a double vision that is a result of what I've described as the partial representation/recognition of the colonial object" (Bhabha, 1994, p.88). It shows the real problem of people who do not have cultural roots. Mainly immigrant people have a similar destiny. Being born into a particular culture, it 
seems as if they do not have any particular culture. They have been victimized by multiculturalism. They come into contact with several cultures.

\section{CONCLUSION}

Hybrid cultural identification is one of the optional cases when a person lives in another culture that cannot go beyond other cultural influences. It is a matter of adjustment where a person cannot exist without having a cultural pattern. It influences a person who adopts some cultural pattern; however, he totally cannot change into a new situation. Both cultural patterns are reflected in a person's behavior or everyday life. Similarly, Tor Baz experiences a hybrid identity along with his shifting from his cultural world. First of all, he belongs own Parsee culture, which is his cultural identity; when he shifts into Mullah Culture where a tribal leader gets him practised all these tribal cultural patterns. However, he cannot forget his own culture as well. At the same time, he lives in between. Having dual cultural standards, he finds both physical and psychological distance from his cultural practices. However, it is a matter of adjustment in a new situation. Tor Baz finds his identity lost. He always feels a lack between his own culture and adopted culture. Finally, he neither becomes Persian nor Mullah or Muslim. Having a hybrid identity is an option for him, so he accepts it and settles down in Afghanistan.

\section{LIMITATION AND STUDY FORWARD}

The study reveals several cultural patterns and influences. Future reseach can be extended to the same genre and the novels written by Pakistani and Indian authors can be taken for further research.

\section{AUTHORS CONTRIBUTION}

Hassan Bin Zubair conceived the main idea of the research. He designed the research methodology, worked on theoretical framework and conducted a major part of data analysis.

Dr. Syeda Sughra Naqviworked on literature review and data analysis.

Saima Larik worked on data analysis and worked on the overall formatting and corrections of the document.

\section{REFERENCES}

1. Ahmad, J. (2011). The Wandering Falcon. New Delhi: Penguin Group.

2. Anderson, D. (1971). 'Ahmed Ali and Twilight in Delhi' in Mahfil. Journal of South Asian Literature, 7(1\& 2), 81-86.

3. Ashcroft, B, et al. (1995). The Post-colonial Studies Reader 2nd Ed. New York: Routledge.

4. Baabar, M. (2011). Islamabad. International The News. (May 22011 ).

5. Bhabha, H. K. (1994). The Location of Culture. London: Routledge.

6. Bose, P.(2008). Home and Away: Diasporas, Developments and Displacements in a Globalising World. Journal of Intercultural Studies, 29(1), 111-131. https://doi.org/10.1080/07256860701759964

7. Cheuse, A. (2011). The Wandering Falcon. Book Reviews (September 27, 2011), 1-3.

8. Desai, G. (2005). Edward Said, Area Studies and Postcoloniality. Rethinking Modernity Ed. Santosh Gupta, Prafulla C.Kar and Parul Dave Mukherji. NewDelhi: Pencraft, 90-98.

9. Espín, O. (2006). Gender, Sexuality, Language, and Migration. Ed. Ramaswami Mahalingam. Cultural Psychology of Immigrants. Mahwah, N.J.: Lawrence Erlbaum, 241-258.

10. Hall, S. (1997). Cultural Identity and Diaspora. Contemporary Post-colonial Theory. A Reader. Ed. Padmini Moniga, Delhi: OUP, 110-21.

11. Hoogvelt, A. (1997). Globalization and the Postcolonial World: The New Political Economy of Development. Baltimore: The John Hopkins University Press. https://doi.org/10.1007/978-1-349-25671-6

12. Jenning, G. (2012). The Land of Blood and Stones: Jamil Ahmad's The Wandering Falcon.Youth Ki Awaazon. (March 12 2012). 180-185.

13. Kaiser, R. (2011). The Wandering Falcon. Books Review, 243-244.

14. Kaleta, K. (1998). Hanif Kureishi: Post-colonial Storyteller. Austin: University of Texas Press. https://doi.org/10.7560/743328

15. Khan, S. (2002). Aversion and Desire: Negotiating Muslim Female Identity in the Diaspora.Toronto: Women's Press.

16. Khan, A. M., Ullah, M., Usman, A., Malik, A. H., Khan, K. M. (2020). Impact of covid-19 on the global economy. International Journal of Management, 11(8), 956-969

17. Lau, L. (2005). Making the Difference: The Differing Presentations and Representations ofSouth Asiain the Contemporary Fiction of Home and Diasporic South Asian Women Writers. Modern Asian Studies, 237-257. https://doi.org/10.1017/S0026749X0400143X

18. Levitt, P., DeWind, J., \& Vertovec, S. (2005). International Perspectives on TransnationalMigration: An Introduction. International Migration Review, 37, 565-575. https://doi.org/10.1111/j.1747-7379.2003.tb00150.x

19. Rath, S. (2003). Home(s) Abroad: Diasporic identities in Third space. Kar, Praffulla C., Kailash C.Baral and Sura P. Rath. Theory and Praxis Curriculum, culture and English studies. New Delhi: Pencraft International, 59. 
20. Sahoo, A. (2006). Issues of Identity in the Indian Diaspora: A Transnational Perspective. Perspectives on Global Development and Technology, 81-97. https://doi.org/10.1163/156915006777354482

21. Thiongo, N. W. (1981). Writers in Politics. London: Heinemann Educational Publishers.

22. Ullah, M. (2020). Women Empowerment and Social Development in Afghanistan through Micro Finance. International Journal of Academic Research in business and Social Sciences, 10(12), 377-389. https://doi.org/10.6007/IJARBSS/v10-i12/8324

23. Young, R. (1995). The Cultural Politics of Hybridity. Colonial Desire. London: Routledge, 643-645. 